\title{
Sharia Fintech Development in Indonesia
}

\author{
Adibah Yahya \\ Universitas Pelita Bangsa, Cikarang Indonesia \\ adibah.yahya@pelitabangsa.ac.id
}

\begin{abstract}
Fintech is a form of financial service innovation other than banks. The more advanced information technology makes fintech as an alternative for the community in financial services. Fintech in Indonesia is divided into conventional and sharia fintech. The development of Islamic fintech in Indonesia continues to increase even though it is still less than conventional fintech. this fundamental difference from Sharia fintech through initial "akad" or agreements between investors and borrowers. Based on data from the Financial Services Authority (OJK) there are 13 licensed and registered Sharia fintech. The types of services performed are payment channel/system, digital banking, online/digital insurance, Peer-to-Peer (P2P) Lending, and crowdfunding. the chance of developing fintech sharia is quite high if it is associated with the number of Muslim population residing in Indonesia which is the largest Muslim population in the world. However, some challenges must be faced including the low level of financial literacy, regulations and sharia fintech policies, as well as service product innovation.
\end{abstract}

Keyword: Fintech, Sharia Fintech, Fintech Services

\section{Introduction}

Technology is a change that cannot be avoided, technology can have both positive and negative impacts. Financial technology is known as financial technology (fintech), the emergence of fintech is expected to be an innovation that is oriented to ease of access, practicality, convenience and more economical costs [1].

The banking service industry in the industrial era 4.0 experienced innovation through technology with the presence of fintech which has great potential in providing solutions to traditional finance [2]. Fintech is a financial service or product innovation that is developed through new technology [3]. Indonesia is a potential market for the development of a populist economy-based Islamic economy because the largest Muslim population in the world is Indonesia [4]. In the economy, Muslims hold the sharia principle, which is to hold rules based on the guidelines contained in the Qur'an and Sunnah. Islam does not prohibit technology as long as it provides benefits to the Ummah. The existence of fintech in the eyes of the Islamic economy according to [5] is an impetus for the advancement of time which is one form of muamalah in Islam.

The development of fintech in Indonesia is inseparable from the highly updated behavior of the Indonesian people in cyberspace. It was noted that one of the biggestconsumers of the internet in the world is the State of Indonesia [6]. Although the Indonesian people are technology literate, financial literacy is very weak. Fintech relies heavily on financial literacy or education in the field of financial technology. By using sharia schemes, Islamic fintech through technological innovation provides responsible and ethical financial services that can open opportunities in influencing all forms of financial globally [2].

Based on the survey of financial literacy sharia in 2016 by the Financial Services Authority (FSA) is only $8.11 \%$ with indicators of service users finance at $11.6 \%$. This shows that the level of education in Islamic finance in Indonesia is very low. When compared with the development of banking, Islamic banking lags far enough so that it requires acceleration. In 
this case, synergy is needed between OJ K and Islamic finance providers with creative and innovative packaging [7].

Islamic banking, takaful, corporative Syariah are Islamic financial institutions that are developing in Indonesia. Even the Islamic capital market is now one of the choices of investors to invest their capital. Sharia Fintech is expected to take a role in filling the sharia financial gap in Indonesia [8]. The gap in question is the distance between financing for micro waqf banks that have a large enough distance if micro waqf banks are only up to Rp 3 million while conventional and Islamic banks reach $\mathrm{Rp} 25$ million.

In 2015, Of the total bank industry in Indonesia, there are $2.83 \%$ of Islamic banks. Compared to Islamic countries that have a smaller economic level, the sharia market share in Indonesia is considered low. Banking growth in Malaysia reached 20\% and Saudi Arabia by $53 \%$ despite having relatively small economic growth compared to Indonesia. supervision and protection is needed for public interactions with the financial services industry for increasing the market share of Islamic banking in Indonesia [9].

Financing corresponding Syariah a potential opportunity as the end of the financial resources early for public utility projects [10]. The development of sharia fintech must be supported by policymakers in academia to be able to balance sharia fintech practices in the academic field. While the challenges faced in Islamic fintech are regulation [11], [12]. the increase in the velocity of money and the economy of the people was driven by the transmission of economic policy which was the impact of the development of fintech in Indonesia which encouraged a national strategy for financial inclusion (SKNI) [13].

\section{Research Methods}

The qualitative descriptive method used in this study refers to data, phenomena or conditions or symptoms that appear in the development of Islamic fintech in Indonesia. The data used is document data in the form of writing, pictures or monumental works of a person [14]. The document collection method is in the form of secondary data about news and the phenomenon of fintech in Indonesia, previous research journals that are related as well as expert opinions on sharia fintech in Indonesia.

\section{Result and Discussion}

\subsection{Development of Fintech Sharia in Indonesia}

Technology that developed rapidly during the industrial revolution 4.0 era provided convenience and practicality. this is felt in the financial sector as well. The development of financial technology in Indonesia gave rise to various financial platforms both conventional and sharia. The development of conventional fintech is accompanied by the development of sharia- based fintech [15]. Fintech sharia in Indonesia arises because of various financial system problems that can be solved with the help of technology, and the suitability of transactions based on sharia rules [16].

The development of a finance company business makes financial regulations as a business reference and system updates in the financial sector. The government's attention to the 
development of financial technology is realized through the rules of fintech and crowdfunding as one of the government's efforts through the Financial Services Authority (OJK). OJK Regulation Number 77/pjok.01/2016 concerning Information Technology-Based Money Lending and Borrowing Services is aimed at fintech operating in Indonesia. The regulation aims to regulate the implementation of fintech through the basis of borrowing and borrowing money to stimulate the growth of financing substitutes for the community.

Conventional and Islamic fintech use OJK regulations regarding financial services information technology, but the principles of Islamic law used in the Islamic fintech industry are not the same as conventional fintech [17]. In addition to sharia fintech referring to the rules of the FSA is also based on the National Sharia Council Fatwa Council of the Indonesian Ulema Council (DSN MUI) Number 117/2018 regarding Financing Services based on Information Technology Based on Sharia Principles.

\subsection{Fintech Syariah at OJK}

The development of the number of fintech in Indonesia is marked by the increase in registered and licensed fintech. The number of fintech lending registered with OJK was 127 companies as of August 7, 2019, with 9 sharia fintech companies. At present as of December 20, 2019, the number of fintech has increased by 164 companies with 13 Islamic fintech companies. OJK still appeals to the public to be wiser in choosing fintech so as not to get caught up in bulging fintech, is encouraged to use the services of fintech that have been registered/licensed from OJK.

The following data is fintech sharia which has a permit and is recorded in the FSA as of December 20, 2019 [18]:

Table 1. Sharia Fintech Registered at OJK

\begin{tabular}{|c|c|c|c|c|c|}
\hline No & Platform & Web & Company & OPeration System & $\begin{array}{r}\text { License/ } \\
\text { Listing }\end{array}$ \\
\hline 1 & Investree & https://www.investree.id & PT Investree Radhika Jaya & Android \& IOS & License \\
\hline 2 & Ammana & https://ammana.id & PT Ammana Fintek Syariah & Android \& IOS & License \\
\hline 3 & Danasyariah & http://danasyariah.id & PT Dana Syariah Indonesia & Android & Listing \\
\hline 4 & Danakoo & www.danakoo.id & PT Danakoo Mitra Artha & Android & Listing \\
\hline 5 & alamisharia & www.p2p.alamisharia.co.id & PT Alami Fintek Sharia & - & Listing \\
\hline 6 & syarfi & www.syarfi.id & PT Syarfi Teknologi Finansial & - & Listing \\
\hline 7 & Duha Syariah & www.duhasyariah.com & PT Duha Madani Syariah & Android & Listing \\
\hline 8 & Qazwa.id & www.qazwa.id & PT Qazwa Madani Syariah & - & Listing \\
\hline 9 & bsalam & www.bsalam.id & $\begin{array}{l}\text { PT Maslahat Indonesia } \\
\text { Mandiri }\end{array}$ & - & Listing \\
\hline 10 & Ethis & http://ethus.co.id & PT Ethis Fintek Indonesia & - & Listing \\
\hline 11 & Kapotas Boost & https://kapitalboost.co.id & PT Kapital Boost Indonesia & - & Listing \\
\hline 12 & $\begin{array}{l}\text { Papitupi } \\
\text { Syariah }\end{array}$ & www.papitupisyariah.com & PT Piranti Alphabet Perkasa & Android & Listing \\
\hline 13 & $\begin{array}{l}\text { Berkah Fintek } \\
\text { Syariah }\end{array}$ & www.finteksyariah.co.id & PT Berkah Finteck Syariah & - & Listing \\
\hline
\end{tabular}

Source: ([18], data processed 2020)

Fintech growth that continues to grow will be more beneficial in the wider community that has not yet experienced fintech if followed by improvements in quality and reach as one of the solutions to fintech development. One of the fintech services that is in great demand is the P2P Lending service, which grew $68.54 \%$ as of June 2019 from the lending of Rp5.04 trillion in 2018, currently reaching Rp.8.5 trillion [19]. 
The ease of access as well as the speed and time efficiency offered also provides the reason for users to choose P2P fintech. To increase transparency towards the addition of sharia products, OJK has issued a checklist on technology-based loan lending and service companies (LPMUBTI). The checklist aims to provide strengthening information technology-based financial services supervision.

\subsection{Sharia Fintech Services}

The most striking difference between conventional fintech and sharia lies in the application of interest or usury. In fintech sharia the nature of the transaction is cooperation, so it is independent of the interest/usury system for borrowers. The revenue sharing system is a system used in cooperation agreed by both parties (the borrower and the investor) [20]. The transactions on Islamic fintech, prioritize the principle of transparency and fairness [8]. OJK as a supervisory institution has not provided definite regulations on the existence of Islamic fintech, so the rules on Islamic and conventional fintech are still the same. The imposition of fines or penalties when a loan is returned before maturity or a customer who repays a loan more than the due date on force majeure is not applied to Islamic companies.

Based on the principle, the MUI National Sharia Council issues a fatwa if Islamic fintech must follow the rules in Islam by not using usury or interest that is not following the provisions. Besides, akad in fintech must also be by mudharabah and musyarakah contracts [21]. The explanation of the contract is as follows:

a) Mudharabah is a business cooperation agreement between an investor and a business operator in which business profits are shared between the two parties according to the agreement, but in the event of a loss, only the capital owner shall bear it.

b) Musyarakah is a contract of cooperation in a particular business consisting of two parties, where all parties contribute to venture capital. The results of good business gains or losses will be borne according to the agreement and do it proportionally.

Fintech services that develop in Indonesia Under the Financial Stability Board (FSB) as an international body of monitors and policy recommendations on the global financial system, divide fintech into four categories based on the type of innovation:

1) Payment, clearing, and settlement, types of innovation services in payments both provided by the banking industry and those conducted by Bank Indonesia.

2) E-aggregator, a type of fintech innovation in data collection or financial information so consumers can utilize this service for decision making in setting up a startup.

3) Risk management and investment, fintech services by providing financial planning in etrading and e-insurance platforms.

4) Peer-to-peer lending (P2P), a fintech service in connecting lending and borrowing services between fund donors (investors) and people who need funds on one platform.

Fintech Syariah offers its main services in the form of peer-to-peer (P2P) loans, crowdfunding, money transfers, mobile payments, trading platforms, wealth management, and insurance. According to the OJK and the Indonesian Ulema Council, sharia fintech in Indonesia who wish to obtain a license must have their own Sharia Superintendent. P2P lending model of Islam, not like conventional banking is based on cost-benefit partnerships, need products for trade financing as physical goods or services (Pişkin \& Kus, 2019).

\subsection{Challenges and Opportunities}

The people who recorded the highest internet usage were in Java with index $(57,70 \%)$, 
Sumatra (19,09\%), Kalimantan (7,97\%), Sulawesi (6,73\%), Bali-Nusa (5,63\%), and MalukuPapua $(2,49 \%)$. The conditions in line according to the quality facilities and infrastructure in Java are relatively better in the match on the territory of others. By age, the productive age population is the most internet user in Indonesia. Nearly half of internet users are people from the age group of $19-34$ years (49.52\%) while the ages of $13-18$ years are $16.69 \%$, ages $35-54$ years are $29.55 \%$, and above the age of 54 years are $4,24 \%$. This $19-34$ years age group is a driving force for the emergence of new professions such as vlogger, YouTuber, selebgram. The mushrooming of start-up companies are also driven by this age group, both of them being business owners and customers. This is in line with the character of the age of 19-34 with a tendency to want to try new things and technological literacy [22].

In improving sharia fintech services, it is necessary to have education about technology to the community, expansion of internet connections, acceleration that leads to an integrated population system so that the information obtained is valid (Yarli, 2018). Besides, Bank Indonesia, a central financial institution, also makes efforts to ensure the convenience and regularity of fintech payment traffic by becoming: facilitators, intelligent business analysts, assessments, and coordinating and communicating [13].

Generally states that there are 3 main obstacles to the development of Islamic fintech in Indonesia, (1) There is illegal fintech, (2) conventional fintech's are registered more easily and varied, (3) Lack of capital, resources, product innovation and marketing [23]. Regulation related to financing fintech is very much needed to minimize risk [23], and it is necessary to educate customers in understanding and knowledge of customers so that they are comfortable and safe in transactions [20].

One of the tasks of Syariah fintech is syiar, therefore Syariah fintech must be able to increase its overall portfolio through cooperation with sharia banking. Besides, innovation is needed in building sharia fintech that can create sharia fintech development in Indonesia [24]. It can be concluded that the challenges facing sharia fintech include: (1) Low in financial litercy;(2) Poor infrastructure support; (3) The need for a mature policy/regulation; (4) Lack of innovation in fintech service features.

Opportunity development of sharia in Indonesia fintech seen in populations of Muslims who constitute the largest population in the world. Sharia Fintech can run according to the provisions that must be shaded by rules supported by the government. The fintech application applied to sharia fintech in Indonesia is by sharia economic principles and values whose development is implemented for sharia social finance such as collection and distribution of zakat, infaq, alms, and endowments.

The opportunities in sharia fintech include, 1) OJK opportunities for sharia fintech players to officially register their fintech in OJK, 2) Ease of technology in investment and donation activities, 3) Illegal fintech cases occurring in the community on conventional fintech, 4) The majority of Indonesian people who are Muslim, 5) The opening of opportunities for the entry of technological developments in Indonesia. Overall the development of Islamic fintech is still quite potential in Indonesia [25].

\section{Conclusion}

The conclusions from the discussion regarding the development of Islamic fintech in Indonesia are as follows:

a) Sharia fintech in Indonesia has experienced growth according to the FSA the number of 
fintech in Indonesia in 2018 reached 9 sharia fintech companies and increased to 13 sharia fintech companies registered at the FSA at the end of 2019.

b) Sharia fintech services in Indonesia consist of payment channel/system, digital banking, online/digital insurance, Peer-to-Peer (P2P) Lending, and crowdfunding.

c) The challenges facing sharia fintech in Indonesia include:

a) The level of sharia financial literacy is still low

b) The lack of support and infrastructure,

c) The need for mature policies and regulations,

d) Lack of innovation in fintech service features

d) Opportunities for fintech sharia are the number of Muslim population in the State of Indonesia which is quite large, as well as the people of Indonesia who are very technologically literate. Besides that's the number of startups is increasing.

a) The opportunity given by OJK for Sharia fintech actors to officially register their fintech in OJK,

b) The ease of technology investment and donation activities,

c) Illegal fintech cases that occur in the community against conventional fintech,

d) The majority of Indonesia's population is Muslim,

e) Opening opportunities for the entry of technological developments in Indonesia.

\section{References}

[1] M. M. Hadad, "Financial Technology (FinTech) di Indonesia," 2017.

[2] A. Parizi, "Perkembangan Fintech Syariah," kseiprogres.com, 2019. [Online]. Available: https://kseiprogres.com/perkembangan-fintech-syariah/. [Accessed: 11-Feb-2020].

[3] D. K. C. Lee and E. G. S. Teo, "Emergence of Fintech and the Lasic Principles," SSRN Electron. $J$., no. January 2015, 2015, doi: 10.2139/ssrn.2668049.

[4] R. P. Irianto, "Fintech Syariah, Masa depan Keuangan Islam," mediaindonesia.com, 2019. [Online]. Available: https://mediaindonesia.com/read/detail/216663-fintech- syariah-masadepan-keuangan-islam.

[5] A. Wira, "Posisi Financial Technology di Mata Ekonomi Islam," fosei-ums.blogspot.com, 2017. [Online]. Available: http://fosei-ums.blogspot.com/2017/12/posisi-financial- technology-dimata.html.

[6] F. Ariyanti, "Peran Penting Fintech 'Primadona' di Era Digital," cermati.com, 2019. [Online]. Available: https://www.cermati.com/artikel/peran-penting-fintech-primadona- di-era-digital.

[7] N. Amalia, "Indeks literasi dan inklusi keuangan syariah rendah," rri.co.id, 2019. [Online]. Available: https://rri.co.id/surakarta/ekonomi-pariwisata/745702/indeks-literasi- dan-inklusikeuangan-syariah-rendah.

[8] R. Y. Wijaya, "Fintech syariah mulai bergairah," mediaindonesia.com, 2019. [Online]. Available: https://mediaindonesia.com/read/detail/272158-fintech-syariah-mulai- bergairah.

[9] A. U. Djawahir, "Keuangan, dan Value Pada Fintech Syariah di Indonesia : Perspektif S- O-R ( Stimulus-Organism-Response ) Model," Annu. Conf. Muslim Sch., no. 01, pp. 439- 448, 2018.

[10] P. Pietro Biancone and M. Radwan, "Sharia-Compliant financing for public utility infrastructure," Util. Policy, vol. 52, no. June, pp. 88-94, 2018, doi: 10.1016/j.jup.2018.03.006.

[11] E. A. Firmansyah and M. Anwar, "Islamic Financial Technology (Fintech): Its Challenges and Prospect,” vol. 216, no. Assdg 2018, pp. 52-58, 2019, doi: 10.2991/assdg-18.2019.5.

[12] A. Rusydiana, "Bagaimana Mengembangkan Industri Fintech Syariah di Indonesia? Pendekatan Interpretive Structural Model (ISM)," Al-Muzara'ah, vol. 6, no. 2, pp. 117- 128, 2019, doi: 10.29244/jam.6.2.117-128. 
[13] bi.go.id, "Financial Technology," bi.go.id, 2019. [Online]. Available: https://www.bi.go.id/id/edukasi-perlindungan-konsumen/edukasi/produk-dan-jasasp/fintech/Pages/default.aspx.

[14] J. . Creswell, Research Design : Pendekatan Metode Kualitatif, Kuantitatif, dan Campuran, 4th ed. Yogyakarta: Pustaka Pelajar, 2016.

[15] D. Yarli, "Analisis akad Tijarah pada transaksi fintech syariah dengan pendekatan maqhasid," Yudisia, J. Pemikir. Huk. dan Huk. Islam, vol. 9, no. 2, pp. 245-256, 2018, doi: 10.1017/CBO9781107415324.004.

[16] M. R. Pasha, "Potensi Besar Perkembangan Fintech Berbasis Syariah di Masa Depan," blog.syarq.com, 2017. [Online]. Available: https://blog.syarq.com/potensi-besar- perkembanganfintech-berbasis-syariah-di-masa-depan-407f696944a8.

[17] M. Rosavina and R. A. Rahadi, "Peer-To-Peer (P2P) Lending Platform Adoption for Small Medium Enterprises (SMEs): A Preliminary Study," Int. J. Accounting, Financ. Bus., vol. 3, no. 10, pp. 1-14, 2018.

[18] OJK, "Statistik Fintech-OJK," Jakarta, 2019.

[19] T. N. Barley, "Jumlah Fintech dan Penyaluran Pinjaman Online Tumbuh Signifikan," financial.bisnis.com, 2019. [Online]. Available: https://finansial.bisnis.com/read/20190823/90/1140051/jumlah-fintech-dan-penyaluran- pinjamanonline-tumbuh-signifikan. [Accessed: 20-Mar-2020].

[20] M. J. Rizki, "Yuk, Mengenal Aturan Main Fintech Syariah," hukumonline.com, 2020. [Online]. Available: https://www.hukumonline.com/berita/baca/lt5ele0a77362a8/yuk-- mengenal-aturanmain-fintech-syariah/.

[21] F. Andriawan, "Mengenal Fintech Syariah, Apa Perbedaannya dengan Konvensional?," paper.id, 2018. [Online]. Available: https://www.paper.id/blog/finansial-umkm/fintech- syariah-diindonesia/.

[22] B. Pracimasanti, "Peluang dan Tantangan Perkembangan Fintech di Indonesia," jambiindependent.co.id, 2019. [Online]. Available: https://jambiindependent.co.id/read/2019/02/16/35806/peluang-dan-tantangan-perkembangan-fintech- $\quad$ diindonesia.

[23] M. Mukhlisin, "Kendala Utama Pengembangan Fintech Syariah," republika.co.id, 2020. [Online]. Available: https://republika.co.id/berita/q4cj9p368/kendala-utama- pengembanganemfintech-emsyariah.

[24] L. Puspaningtyas, "Fintech Syariah Berpotensi Tingkatkan Porsi Ekonomi Syariah," $\begin{array}{lll}\text { republika.co.id, } 2019 . & \text { [Online]. Available: }\end{array}$ https://www.republika.co.id/berita/pya72e370/fintech-syariah-berpotensi-tingkatkan- porsiekonomi-syariah.

[25] H. Hiyanti, L. Nugroho, C. Sukmadilaga, and T. Fitrijanti, "Peluang dan Tantangan Fintech (Financial Technology) Syariah di Indonesia," J. Ilm. Ekon. Islam, vol. 5, no. 3, pp. 326-333, 2020, doi: 10.29040/jiei.v5i3.578. 